\title{
ИССЛЕДОВАНИЕ ТЕХНИЧЕСКИХ ПОКАЗАТЕЛЕЙ СЕМЯН ЛЬНА БЕЛОГО И КОРИЧНЕВОГО ДЛЯ ПРИМЕНЕНИЯ В ПИЩЕВОЙ ПРОМЫШЛЕННОСТИ
}

\author{
К.Н. Нициевская, Г.П. Чекрыга, О.К. Мотовилов
}

Проведен анализ (сравнение, синтез, обобщение) литературных данных по химическому составу семян льна и их применение в пищевой и фрармацевтической промышленности. Проанализирован процесс измельчения семян льна белого и коричневого по визуальным, осязательным и обонятельным характеристикам - «зернистость», «влажность», «жирность», «клейкость». Рассмотрены изменения семян исследуемых сортов льна в процессе гидратации по показателям - «содержание не гидратированной воды», «появление пены», «выделение слизи» и "вязкость раствора», указывающие на взаимосвязь с химическим составом используемых семян. Проведена сравнительная оценка монокомпонентной муки (рисовой, кукурузной, амарантовой) и муки из семян льна разных сортов для приготовления жареных хлебобулочных изделий. Изучены органолептические показатели образцов опары и готовых изделий. Получены данные о возможности использования семян льна белого и коричневого при получении жареных хлебобулочных изделий.

Ключевые слова: лен белый, лен коричневый, текстура, опара, жареное хлебобулочное изделие, гидратация, мука.

\section{ВВЕДЕНИЕ}

Одним из условий разработки продуктов питания является выбор оптимальных технологических режимов, обеспечивающих получение продукта с необходимыми функциональными свойствами.

Основным направлением развития перерабатывающей отрасли является внедрение ресурсосберегающих технологий в сочетании с принципами пищевой комбинаторики. Это позволяет осуществлять глубокую переработку сырья, обеспечивая население продуктами нового поколения, снижение себестоимости и повышение конкурентоспособности создаваемых продуктов.

Перспективным является поиск растительных гипоаллергенных культур, одним из которых являются семена льна.

В настоящее время семена льна используют в фармацевтической промышленности, как составляющее препаратов [1-3], основное действие которых направлено на улучшение зрения (сетчатки глаза); функции надпочечной железы, щитовидной железы и т.д. Семена льна содержат компоненты, способные предупредить или снизить риск возникновения некоторых видов раковых заболеваний [4-6]. Стебли и листья содержат гликозид линамарин, около 20 фенолкарбоновых кислот. В оболочках семян найдены линокофеин, линоцинамарин, глюкозид линамарин и метиловый эфир Р-окси-р-метилглутаровой кислоты, водорастворимые пентозаны (слизи), препятствующие всасыванию из кишечника ядовитых веществ, образующихся при инфекционных заболеваниях. Гликозид линамарин, регулирует секреторную и моторную функции кишечника. Семена льна обладают обволакивающим, легким слабительным и противовоспалительным действием. Благодаря своим высокобелковым свойствам семена льна используют в технологии получения хлебобулочных изделий в виде цельных семян [7-11].

Своеобразие химического состава семян льна обусловлено витаминно-минеральным комплексом. Содержание масла колеблется от 30 до $48 \%$, в состав которого входят глицериды - линоленовая (омега - 3) от 35 до 45 $\%$, линолевая (омега - 6) от 25 до $35 \%$, олеиновая от 15 до $20 \%$, пальмитиновая и стеариновая от 8 до $9 \%$ кислоты. Содержание слизей от 5 до $12 \%$, белка от 18 до $33 \%$, углеводов от 12 до $26 \%$, значительное количество макро- и микроэлементов. Витамины представлены (в пересчете на сухое обезжиренное вещество), мг/100 г продукта: тиамина - 8,8; рибофлавина - 0,004; ниацина $-0,101$; пантотеновая кислота $-0,031$ и холина $-4,9$ $[5,6,8,9]$

Согласно ТР ТС 027/ 2012 [12] продукты на основе семян льны относятся к специализированной группе - диетического лечебного и диетического профилактического питания.

Цель работы: изучение технических показателей семян льна белого и коричневого для применения в пищевой промышленности 


\section{МАТЕРИАЛЫ И МЕТОДЫ ИССЛЕДОВАНИЙ}

Объектами исследования являлись семена льна белого (фирмы Биокор), коричневого (фирмы Сибирская масляная компания) пищевых сортов, образцы жареных хлебобулочных изделий.

Методы проведения работы теоретические (анализ, синтез, обобщение литературных данных) и экспериментальные (физико-химические, органолептические).
Измельчение семян проводили в сухом виде аппаратом, снабженным режущими ножами. Оценивали по показателям: визуально (внешний вид, цвет), осязательно (текстура (консистенция)) и обонятельно (запах).

Исследование текстуры образцов заключалось в анализе показателей по балловой шкале согласно ГОСТ ISO 5492-2014 [13] в таблице 1

Таблица 1 Органолептический профиль текстуры образцов из семян льна

\begin{tabular}{|l|l|l|l|l|l|}
\hline Показатель & 5 баллов & 4 балла & 3 балла & 2 балла & балл \\
\hline Зернистость & Порошкообразная & Песчанистая & Зернистая & $\begin{array}{l}\text { Гранулирован- } \\
\text { ная }\end{array}$ & $\begin{array}{l}\text { Грубая ком- } \\
\text { коватая }\end{array}$ \\
\hline Влажность & Сухая & Влажная & Мокрая & & \\
\hline Жирность & Маслянистая & Жирная & Салистая & & \\
\hline Клейкость & Рассыпчатая & Рыхлая & Липкая & Клейкая & \\
\hline
\end{tabular}

Изучение гидратации семян проводили по следующей методики. К семенам льна (в целом и измельченном виде) в количестве 10 г. добавляли воду в количестве 200 мл (температура воды $\left.80 \pm 2^{\circ} \mathrm{C}\right)$ и выдерживали в течении 30 минут. Затем определяли: влагоемкость целых и измельченных семян, количество негидратированной воды и её свойства: пенообразование, образование слизи, вязкость раствора.

Метод приготовление опары включал замес из измельченных семян льна, муки (рисовой / кукурузной / амарантовой), воды и хлебопекарных дрожжей. Полученные образцы полуфрабриката обжаривали до готовности на подсолнечном масле по ГОСТ 1129-93 [14].
Методика исследования органолептических показателей: визуальные (внешний вид: форма, цвет, состояние поверхности, целостность, пропеченность, пористость, структура и цвет мякиша), осязательные (консистенция), обонятельные (запах (аромат)) и вкусовые (вкус) согласно ГОСТ 31751-2012 [15]. Изменения в процессе измельчения, гидратации и при приготовлении жареных хлебобулочных изделий

\section{РЕЗУЛЬТАТЫ ИССЛЕДОВАНИЙ}

Влияние «измельчения семян льна» оценивали по показателям: внешний вид, текстура, запах полученного продукта (таб. 2).

Таблица 2 Характеристика текстуры образцов из семян льна

\begin{tabular}{|c|c|c|c|}
\hline \multirow[b]{2}{*}{$\begin{array}{l}\text { Показатели тек- } \\
\text { стуры }\end{array}$} & \multicolumn{2}{|c|}{ Семена льна } & \multirow{2}{*}{$\begin{array}{c}\text { Показатель в } \\
\text { баллах (образец №1/ } \\
\text { №2), балл }\end{array}$} \\
\hline & $\begin{array}{c}\text { Белый } \\
\text { (образец №1) }\end{array}$ & $\begin{array}{l}\text { Коричневый } \\
\text { (образец №2) }\end{array}$ & \\
\hline Зернистость & Песчанистый & $\begin{array}{l}\text { Зернистый, ком- } \\
\text { коватый }\end{array}$ & $4 / 2$ \\
\hline Влажность & Влажная & Мокрая & $5 / 4$ \\
\hline Жирность & Маслянистый & Салистый & $5 / 3$ \\
\hline Клейкость & Рассыпчатый & Рыхлый, липкий & $5 / 3$ \\
\hline Внешний вид & $4,8 \pm 0,3$ & $4,5 \pm 0,2$ & \\
\hline Запах & $4,8 \pm 0,2$ & $4,3 \pm 0,3$ & \\
\hline
\end{tabular}

Оболочка семян белого льна (образец №1) имела более тонкую структуру, чем коричневого, что повлияло на текстуру - песчанистость, зернистость и рассыпчатость полученного образца.
Образец №1 имел - рассыпчатую, влажную и маслянистую текстуру при сдавливании происходило образование комков. Внешний вид был однородным с включениями частиц оболочки от светло-желтого до желтого цвета, запах приятный зерновой. 
Образец №2, полученный из семян коричневого льна зернистый с наличием частиц оболочки семян. Внешний вид: был неоднородный с включениями частиц оболочки крупнее основных, цвет от светлокоричневого до коричневого, запах кормовой, маслянистый.
Образец № 2 был липким, клейким, рыхлым с образованием комков при сдавливании (рис. 1). Исследование образцов при гидратации заключалось в анализе показателей «зернистость», «влажность», «жирность», «клейкость» по балловой шкале (табл.1).

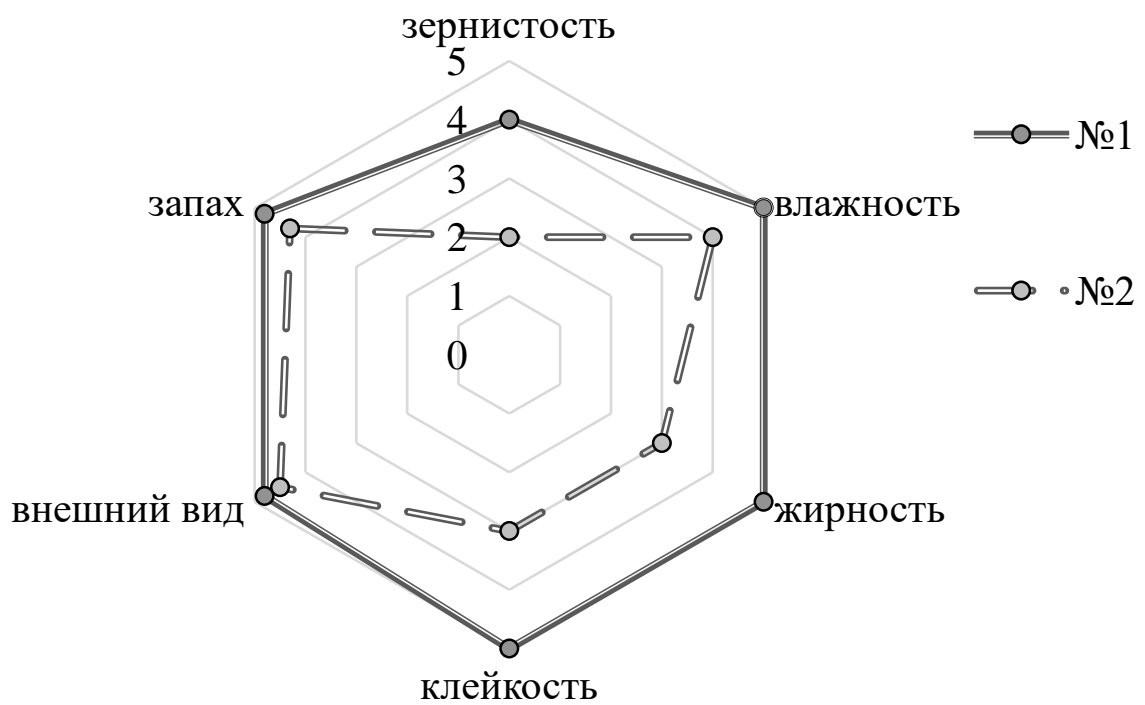

Рисунок 1 - Текстура образцов измельченных семян белого и коричневого льна (балл)

В образцах с использованием цельных семян льна наблюдали образование прозрачной слизи на поверхности воды, незначительное помутнение, маслянистость раствора, вспенивание при перемешивании смеси, набухание зерен в 3 раза. Результаты остаточного содержания воды свидетельствуют о высокой водосвязывающей способности на молекулярном уровне (табл. 3).

Таблица 3 Характеристика семян льна в процессе гидратации и измельчения

\begin{tabular}{|c|c|c|c|c|c|c|c|c|}
\hline \multirow[b]{2}{*}{$\begin{array}{l}\text { № } \\
\Pi / \Pi\end{array}$} & \multirow[b]{2}{*}{ Сорт льна } & \multirow[b]{2}{*}{$\begin{array}{c}\text { Гидромодуль } \\
\text { семян льна к } \\
\text { воде, ед }\end{array}$} & \multirow[b]{2}{*}{$\begin{array}{c}\text { Кол-во не } \\
\text { гидратиро- } \\
\text { ванной во- } \\
\text { ды, мл }\end{array}$} & \multicolumn{5}{|c|}{$\begin{array}{c}\text { Характеристики } \\
\text { не гидратированной воды }\end{array}$} \\
\hline & & & & 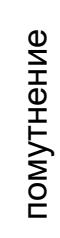 & 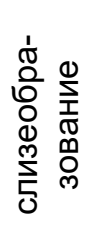 & 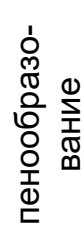 & 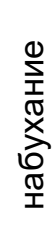 & 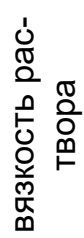 \\
\hline \multirow{2}{*}{$\begin{array}{l}\frac{0}{0} \\
\underline{1} \\
0 \\
0 \\
\stackrel{0}{コ}\end{array}$} & $\begin{array}{c}\text { Белый } \\
\text { (образец №1) }\end{array}$ & $1: 20$ & 120 & + & + & + & + & + \\
\hline & $\begin{array}{l}\text { Коричневый } \\
\text { (образец №2) }\end{array}$ & $1: 20$ & 152 & + & + & + & + & + \\
\hline \multirow{2}{*}{ 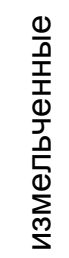 } & $\begin{array}{c}\text { Белый } \\
\text { (образец №3) }\end{array}$ & $1: 20$ & 120 & + & - & - & + & - \\
\hline & $\begin{array}{c}\text { Коричневый } \\
\text { (образец №4) }\end{array}$ & $1: 20$ & 110 & + & + & + & + & + \\
\hline
\end{tabular}


Гидратация образца №1 из семян льна белого. Не гидратированная вода, была белого цвета, происходило растворение белков в водной фракции. Осадок без слизи, но вязкий, что указывает на крахмалистость сорта. Незначительное содержание слизи и отсутствие пенообразования при перемешивании смеси - разрушение околоплодной оболочки и распределение жировых пленок в измельченном виде в продукте. Количество негидратированной воды находилось в пределах $120 \pm 3$ мл.

Гидратация образца №2 из семян льна коричневого. Выделение слизи на поверхности не гидратированной воды, помутнение и высокая вязкость, вспенивание при перемешивании, набухание зерен в 3 раза. Остаточное содержание негидратированной воды и помутнение раствора свидетельствует о высоком содержании жира и жироподобных соединений в верхних слоях оболочки. Раствор имел вязкий бело-серый цвет. Количество негидратированной воды находилось в пределах $152 \pm 3$ мл.
Образец №3 из измельченных семян льна белого имел хорошую набухаемость. Имел вязкий зернистый вид с наличием частиц оболочки и слипание частиц по всей массе. Запах приятный, зерновой. Количество негидратированной воды было в пределах $120 \pm 2$ мл.

Образец №4, полученный из измельченных семян коричневого льна был мутным светло-коричневого цвета за счет пигментов оболочки семян. Масса с частицами оболочки отличалась комковатостью, слипаемостью частиц. Маслянистость оболочки семян затрудняло отделение водной части. Образец имел хорошую набухаемость, текстура кашеобразная с наличием частиц оболочки. Запах масляный. Количество негидратированной воды находилось в пределах 110 3 мл.

Для сравнения жареных хлебобулочных изделий из семян льна белого и коричневого использовали других виды монокомпонентной муки. Разработка рецептуры экспериментальных образцов представлены в табл. 4.

Таблица 4 - Разработка рецептуры

\begin{tabular}{|c|c|c|c|c|c|}
\hline \multirow[t]{2}{*}{ наименование компонентов } & \multicolumn{5}{|c|}{ образцы рецептур } \\
\hline & №1 & №2 & №3 & №4 & №5 \\
\hline белый лен* & + & & & & \\
\hline коричневый лен* & & + & & & \\
\hline рисовая мука & & & + & & \\
\hline кукурузная мука & & & & + & \\
\hline семена амаранта* & & & & & + \\
\hline вода & + & + & + & + & + \\
\hline дрожжи & + & + & + & + & + \\
\hline \multicolumn{6}{|c|}{ Результаты исследований } \\
\hline опара (подъемность) & средняя & низкая & средняя & высокая & низкая \\
\hline набухаемость & высокая & высокая & низкая & средняя & низкая \\
\hline \multicolumn{6}{|c|}{ Образцы жареных хлебобулочных изделий } \\
\hline пропеченность & + & + & - & + & - \\
\hline пористость & + & + & - & - & - \\
\hline цвет мякиша & светлый & $\begin{array}{l}\text { светло- } \\
\text { желтый }\end{array}$ & $\begin{array}{l}\text { светло- } \\
\text { желтый }\end{array}$ & $\begin{array}{c}\text { светло- } \\
\text { коричневый }\end{array}$ & коричневый \\
\hline
\end{tabular}

При приготовлении опары для жареных изделий образцы отличались подъемностью и текстурой готовых изделий. Используемые сорта муки относятся к категории безглютеновой продукции и являются диетическими. Апробированы жареные хлебобулочные изделия, состоящие только из монокомпонентной муки:

- рисовой муки - подъемность опары средняя, набухаемость низкая. При жарке увеличение объема в 3 раза, на срезе пористость, пропеченность, отсутствие специфических запахов и привкусов, цвет мякиша белый;
— кукурузной муки - набухаемость средняя и подъемность опары высокая. При жарке увеличение объема в 2,5 раза, карамелизация поверхности (изменение цвета от желтого до коричневого). На срезе пористость, пропеченность, отсутствие специфических запахов и привкусов, цвет мякиша от светложелтого до желтого;

- амарантовой муки - подъемность опары низкая, набухаемость средняя. При жарке увеличение объема в 1,3 раза, на срезе незначительная пористость, низкая пропеченность, наличие зернового запаха и вкуса, 
цвет мякиша от светло-коричневого до коричневого;

—льняной муки (лен коричневый) набухаемость высокая и подъемность опары низкая. При жарке не отмечено увеличения в объеме изделия, на срезе низкая пропеченность, наличие маслянистого запаха и вкуса, цвет мякиша от коричневого до темнокоричневого;

— льняной муки (лен белый) - набухаемость высокая и подъемность опары средняя. При жарке не отмечено увеличения в объеме изделия, на срезе низкая пропеченность, наличие зернового запаха и вкуса, цвет мякиша от светло-коричневого до коричневого.

Результаты исследований подтвердили, что наилучшими определены образцы из семян льна белого.

\section{ВЫводы}

Перспективным является использованием семян белого льна для разработки рецептур хлебобулочных изделий и других продуктов на его основе, как диетического лечебного и диетического профилактического питания.

\section{СПИСОК ЛИТЕРАТУРЫ}

Способ приготовления растительного молока из семян льна // Патент России №2333656. 2008 Бюл. № 26 / Миневич И.Э., Григорьева А.Л.

Способ получения комбинированного молочно-растительного продукта // Патент России №2142716. 1999 / Полянский К.К., Родионова Н.С

Фитосбор лекарственных растений для комплексной терапии заболеваний печени и желчевыводящих путей // Патент России №2606838. 2017 Бюл. № 1 / Фархутдинов Р.Г., Гильмутдинова Л.Т., Маракаева Е.А.

Краус С., В. Иунихина и др. Хлеб для функционального питания // Хлебопродукты. - 2003. №2. - C.44.

Краснова Н.С., Пуриче Ж.В., Чикала Т.Е. Химический состав, функциональные свойства и перспективы использования соевых белковых продуктов в хлебопечении // Хранение и переработка сельхозсырья. - 2001. №4. - C.43-44.

Миневич И. Использование семян льна в хлебопечении / И. Миневич, В. Зубцов, Т. Цыганова // Хлебопродукты. - 2008. № 3. - С.38-40

Пащенко Л.П., Коваль Л.А., Пащенко В.Л. Печенье из овсяной муки с применением семян масличного льна // Современные наукоемкие технологии. - 2006. № 6 - С. 54-55.

Пащенко Л.П., Коваль Л.А., Пащенко В.Л. Применение семян масличного льна в мучных кондитерских изделиях // Современные наукоемкие технологии. - 2006. № 6 - С. 95-96.

Пащенко Л.П,, Коваль Л.А., Пащенко В.Л. Функциональные свойства семян масличного льна
// Успехи современного естествознания. - 2006. № $10-$ C. $98-99$

Лекарственный сбор растений для лечения сердечно-сосудистых заболеваний // Патент России №2484843. 2013 Бюл. № 17 / Пехтерев А.К.

Способ получения средства, обладающего иммуномодулирующей активностью // Патент России №2496510. 2013 Бюл. № 30 / Нагаслаева О.В., Хобракова В.Б., Николаева Г.Г., Асеева Т.А., Николаев С.М., Банзаракшеев В.Г.

TP TC 027/2012 О безопасности отдельных видов специализированной пищевой продукции, в том числе диетического лечебного и диетического профилактического питания / [Электронный ресурс]. - Режим доступа: URL: http://certtest.ru/ru/perechen-tr-ts.html (дата обращения 12.03.2018)

ГOCT ISO 5492-2014 Органолептический анализ. Словарь / [Электронный ресурс]. - Режим доступа: URL: http://www.internetlaw.ru/gosts/gost/58300/ (дата обращения 12.03.2018)

ГОСТ 1129-93 Масло подсолнечное. Технические условия / [Электронный ресурс]. - Режим доступа: URL: http://www.internetlaw.ru/gosts/gost/44503/ (дата обращения 12.03.2018)

15 ГОСТ 31751-2012 Изделия хлебобулочные жареные. Общие технические условия / [Электронный ресурс]. - Режим доступа: URL: http://www.internet-law.ru/gosts/gost/53535 (дата обращения 12.03.2018)

\section{Нициевская Ксения Николаевна}

Сибирский научно-исследовательский и технологический институт переработки сельскохозяйственной продукции Федерального государственного бюджетного учреждения науки Сибирского федерального научного чентра агробиотехнологий Российской академии наук, ФГБОУ ВО Новосибирский ГАУ, г. Новосибирск, Россия, aksuta88@bk.ru

\section{Чекрыга Галина Петровна}

Сибирский научно-исследовательский и технологический институт переработки сельскохозяйственной продукции Федерального государственного бюджетного учреждения науки Сибирского фредерального научного центра агробиотехнологий Российской академии наук, г. Новосибирск, Россия, GNU ip@ngs.ru

\section{Мотовилов Олег Константинович}

Сибирский научно-исследовательский и технологический институт переработки сельскохозяйственной продукции Федерального государственного бюджетного учреждения науки Сибирского федерального научного центра агробиотехнологий Российской академии наук, г. Новосибирск, Россия, GNU ip@ngs.ru 